\title{
The Impact of Advertising Appeals on Purchase Intention
}

\section{in Social Media Environment_—Analysis of Intermediary}

\section{Effect Based on Brand Attitude}

\author{
Qian $\mathrm{He}^{1}$ \& Hongjian $\mathrm{Qu}^{1}$ \\ ${ }^{1}$ Shanghai University of Engineering Science, China \\ Correspondence: Qian He, Shanghai University of Engineering Science, China
}

Received: May 20, 2018

Accepted: May 31, 2018

Online Published: June 14, 2018

doi:10.5430/jbar.v7n2p17

URL: https://doi.org/10.5430/jbar.v7n2p17

\begin{abstract}
Social media, represented by WeChat and micro-blog, has become an indispensable communication tool for human beings. The social media advertising that extends in this environment has also become the focus of enterprise marketing. Based on the brand attitude as the intermediary variable, this paper studies the influence of advertising appeal on the purchase intention under the socialized media environment, and tries to clarify the influence mechanism between the advertising appeal and the consumer purchase intention. Through the related literature, we find out the relationship between the advertising appeal and the brand state and the purchase intention. Put forward relevant research proposals, to enterprises in the social media environment advertising marketing pointed out a new direction.
\end{abstract}

Keywords: social media advertising appeal purchase intention brand attitude

\section{Introduction}

With the rapid development of the times, the network has become the mainstream of people's life, and it is derived from the social media to bring more convenience to the people's life, at the same time, it also brings more business opportunities to the enterprises. Social media has shown the future of "blowout" development and "scale". Social media is changing the way people use information and way of life (Yu Ting Ting, 2013), the typical WeChat in social media is not only the most widely used communication tool, but also the marketing platform for many enterprises. The prevalence of micro business can be observed in a large number of invisible advertising into our circle of friends, and advertising marketing in social media has been common. Advertising appeal is the embodiment of advertising marketing. Liu Jianxin studies the promotion of value and sales by spreading the scarce demand of pre sold goods to the target consumers. It has become an important marketing strategy for many enterprises, and explores the multiple intermediary mechanism of product scarcity appeal that affects consumers' desire for purchase (Liu Jianxin, 2017), the purpose of this study is to explore how advertising appeal affects purchasing intention under the social media environment, and to introduce the intermediary variable brand attitude, trying to find out the relevance and finding more marketing ideas for the enterprise.

\section{Theoretical Analysis, Research Hypothesis and Logical Model Construction}

(One) Theoretical analysis and research hypothesis

According to the standard attitude change model proposed by American psychologist Hovland (Hovland) in 1959, external stimuli can affect the change of people's attitude. According to the theory and plan of rational behavior and planning proposed by American scholar Fishbein and Ajzen in 1975, it can be seen that individual attitudes affect them. Behavior intention, and then influence individual behavior. In this study, the external stimulus is the advertising appeal, and the social media is the big environment, and then the influence of the advertising appeal on the purchase behavior under the social media environment is explored, and the purchase intention of the variable is taken as the measured index of the purchase behavior. Wang Xia studies the different brand personality, the intensity of advertising appeal affects consumption directly. Willingness to purchase (Wang Xia, 2012), Chen Kai found that compared to altruistic advertising demands, self serving advertising appeals can stimulate consumers' willingness to buy green (Chen Kai, 2016). After receiving the external stimulus, people will have a change of attitude according to 
the theory of rational behavior. Therefore, this study thinks that the brand attitude of the consumer will change in the process of advertising appeal affecting purchase intention, and the influence of the advertising appeal on the purchase intention is mediating, and the research into the brand attitude is the intermediary change. Chen Dong studied different advertising appeals, and perceived brand value positively influenced brand identity (Chen Dong, 2014), Yuan Denghua studied rational appeals advertising compared with emotional appeals advertising can drive consumers to a more positive brand attitude toward crisis brands (Yuan Denghua, Luo Siming, Fu Chun Jiang, Xie Ying Qin, 2010). This study divides advertising appeals into perceptual advertising appeals and rational advertising appeals, classifying brand attitudes into brand emotions and brand trust.The following hypothesis are obtained:

Hypothesis 1: advertising appeal is positively affecting purchase intention;

Hypothesis 2: brand trust plays an intermediary role in the impact of advertising appeals on purchase intention.

Hypothesis 3: brand sentiment plays an intermediary role in the impact of advertising appeals on purchase intention.

(Two) Construction of a theoretical model

According to the research hypothesis, the theoretical model of this paper is as follows:(Fig.1):
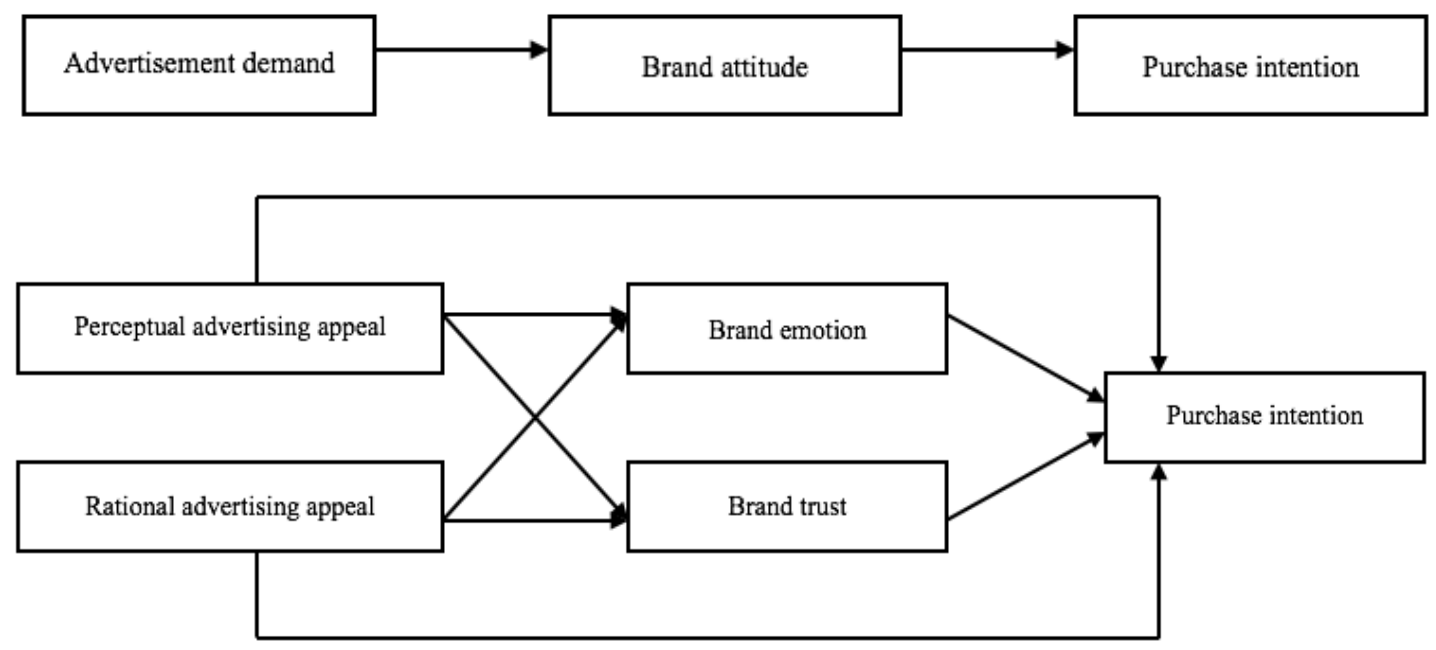

Figure 1. The theoretical model of this study

\section{Research and Design}

(One) The selection and measurement of variables

1. Advertising appeals under the environment of social media

Wang Huaiming divides advertising appeals into perceptual advertising appeals and rational advertising appeals (Wang Huaiming, Chen Yiwen, 1999), the selection of the following scale is based on the selection of scale based on social media. The characteristics of social media are virtual, network, and communication between people are realized through network tools. The appeal of perceptual advertising is mainly by stimulating consumers' emotion, focusing on the psychological changes of consumers. By transferring spiritual meaning, moving consumers or affecting consumers' emotional fluctuation, this study is based on the characteristics of social media to divide the appeal of perceptual advertising into 3 parts, respectively. Music, interaction and interpersonal influence, select advertising to make consumers feel interesting, relaxed and happy; interact with others, meet friends, interact with businesses; disseminator influence, intimate relationship, popularity, these 9 measurement indicators to measure the perceptual advertising appeal. The appeal of rational advertising mainly through the display of product characteristics, performance and use, based on scientific theory, through functional and data and other rational logic to move consumers, so that the feeling is very credible, and then affect the purchase behavior (Wang Huaiming, 1999). Based on the characteristics of social media, this paper divides rational advertising into function, credibility and participation. It selects advertising to make consumers understand information, master skills and broaden knowledge; the content is true, accurate and no exaggeration; they pay attention to, cover the coverage and actively respond to these 9 indicators to measure rational advertising appeals. 


\section{Brand attitude}

According to Percy and Rossiter (1992), brand attitude is defined as the overall evaluation of consumers' ability to meet their own needs and goals, and that brand attitude includes both cognitive and emotional factors. Sengupta and Fitzismon (2000) define brand attitude as the psychological internal assessment of brand generation when purchasing decision makers accept the stimulus from the information from the brand attributes (Li Qiong, Wu Zuomin, 2008). Xie Yi divided the brand attitude into brand trust and brand sentiment, and studied the uncertainty of consumer attitude and attitude (Xie Yi, Peng Siqing, 2014); brand emotion is the emotional impression that the consumer produces to a brand (merchant). The brand emotion will affect the consumer's purchase. This study chooses to use happiness, feel happy, brings fun and enjoy the process, and measure the brand emotion through these 4 indexes; Select Trust merchants, trustworthy and sincere. The 4 variables are real and reliable to measure brand trust.

\section{Purchase intention}

Fishbein (1975) thinks that customer purchase intention refers to the subjective probability of buying behavior (Fishbein M, Ajzen I., 1975), Mullet (1985) thinks that purchase intention is formed by the subjective choice of consumers in the process of cognition of products through the stimulation of external conditions (Gary M. Mullet \& Marvin Karson), Nena (2003) proposed that the purchase intention will directly affect the purchase behavior, which is the direct indicator of the purchase behavior of the customer (Nena Lim, 2003). It is defined as whether the consumer is willing to understand the product or not, whether there is a purchase intention or not, combined with the characteristics of the social media, it selects the point strike link, the purchase, and the purchase of other platforms. Buy and will go to the physical store to purchase these 4 indicators to comprehensively measure the consumers' purchase intention. 
The measurement scale of each index is shown in Table 1.

Table 1 . This study measurement scale

\begin{tabular}{|c|c|c|c|}
\hline variable & dimension & $\begin{array}{l}\text { Measurement } \\
\text { dimension }\end{array}$ & Operational questionnaire \\
\hline \multirow{9}{*}{$\begin{array}{l}\text { Appeal of } \\
\text { perceptual } \\
\text { advertisement }\end{array}$} & \multirow{3}{*}{ For entertainment } & $\begin{array}{l}\text { Interesting } \\
\text { content }\end{array}$ & The content of social media ads is interesting \\
\hline & & Lighthearted & The content of social media ads is easy and enjoyable \\
\hline & & Happy & The content of social media advertising makes me feel happy. \\
\hline & \multirow{3}{*}{$\begin{array}{l}\text { interactive } \\
\text { quality }\end{array}$} & $\begin{array}{l}\text { Social } \\
\text { interaction }\end{array}$ & $\begin{array}{l}\text { I can interact with others through the content of social media } \\
\text { advertisements. }\end{array}$ \\
\hline & & $\begin{array}{l}\text { Get acquainted } \\
\text { with new } \\
\text { friends }\end{array}$ & Through social media advertising, I can get to know more friends. \\
\hline & & $\begin{array}{l}\text { Brand } \\
\text { interaction }\end{array}$ & $\begin{array}{l}\text { Social media advertising enables me to interact effectively with } \\
\text { the event organizers. }\end{array}$ \\
\hline & \multirow{3}{*}{$\begin{array}{l}\text { Interpersonal } \\
\text { influence }\end{array}$} & Effect & The communicators of social media ads are more influential \\
\hline & & Intimacy & The communicators of social media are intimately related to me. \\
\hline & & Popularity & $\begin{array}{l}\text { The disseminators of social media advertising have a high } \\
\text { reputation. }\end{array}$ \\
\hline \multirow{9}{*}{$\begin{array}{l}\text { Rational } \\
\text { advertising } \\
\text { appeal }\end{array}$} & \multirow{3}{*}{ Function } & $\begin{array}{l}\text { Understanding } \\
\text { information }\end{array}$ & Social media ads make me know the latest information \\
\hline & & Mastery of skill & I've got some new skills in social media advertising \\
\hline & & $\begin{array}{l}\text { Widening } \\
\text { knowledge }\end{array}$ & Social media ads make me more knowledge-based \\
\hline & \multirow{3}{*}{ Trustworthiness } & real & The content of social media ads is relatively true \\
\hline & & accuracy & The content of social media ads is relatively accurate \\
\hline & & $\begin{array}{l}\text { No } \\
\text { exaggeration }\end{array}$ & The content of social media ads is not particularly exaggerated \\
\hline & \multirow{3}{*}{$\begin{array}{l}\text { Participation } \\
\text { degree }\end{array}$} & $\begin{array}{l}\text { Other people's } \\
\text { attention }\end{array}$ & Most people will pay attention to social media advertising \\
\hline & & Coverage & Social media ads cover a lot of users \\
\hline & & Active response & Most people are actively responding to social media ads \\
\hline \multirow{4}{*}{ Brand emotion } & \multirow{4}{*}{ Brand emotion } & I feel fine & $\begin{array}{l}\text { I feel very good when I use products advertised by social media } \\
\text { commercials. }\end{array}$ \\
\hline & & $\begin{array}{l}\text { In a cheerful } \\
\text { frame of mind }\end{array}$ & $\begin{array}{l}\text { Businessmen from social media advertising give me a very } \\
\text { pleasant feeling. }\end{array}$ \\
\hline & & Bring fun & The business of social media ads brings me a lot of fun \\
\hline & & $\begin{array}{l}\text { Enjoy the } \\
\text { experience }\end{array}$ & $\begin{array}{l}\text { As a customer of social media advertising, it is a very enjoyable } \\
\text { experience. }\end{array}$ \\
\hline \multirow{4}{*}{ Brand emotion } & \multirow{4}{*}{ Brand emotion } & confidence & I trust the business of social media advertising \\
\hline & & trust & I think the business of social media advertising is trustworthy. \\
\hline & & honest & I think the business of social media ads is honest. \\
\hline & & reliable & I think the business of social media ads is reliable \\
\hline \multirow{4}{*}{$\begin{array}{l}\text { Purchase } \\
\text { intention }\end{array}$} & \multirow{4}{*}{$\begin{array}{l}\text { Purchase } \\
\text { intention }\end{array}$} & $\begin{array}{l}\text { Willing to } \\
\text { understand }\end{array}$ & $\begin{array}{l}\text { I will click on links in social media advertisements to further } \\
\text { understand the situation. }\end{array}$ \\
\hline & & Willing to buy & I'm going to buy products recommended for social media ads \\
\hline & & $\begin{array}{l}\text { Platform } \\
\text { purchase }\end{array}$ & $\begin{array}{l}\text { I will buy goods from other platforms through links in social } \\
\text { media advertisements. }\end{array}$ \\
\hline & & $\begin{array}{l}\text { Under line } \\
\text { purchase }\end{array}$ & $\begin{array}{l}\text { I will buy products recommended by social media advertisements } \\
\text { in physical stores. }\end{array}$ \\
\hline
\end{tabular}


(Two) Selection of samples and data collection

This study validates the model through questionnaire survey and data analysis. 700 questionnaires are issued, 688 copies are issued, and the recovery rate of questionnaires is $98 \%$. Among them, 672 questionnaires are valid and the efficiency of the questionnaire is $97 \%$.

(Three) Descriptive statistics

Among the statistical samples of this study, men accounted for $43.2 \%$, women accounted for $56.8 \%$, and the distribution was more uniform; age distribution was 18 and below $2.96 \%, 18$ years old -35 years accounted for $85.21 \%$, 35 year old -60 years accounted for $11.83 \%, 60$ years and more than $0 \%$. It is known that the age of the respondents was mainly at the age of -35 in 18 years, the most used for social media. The frequency of the age stage; the degree of education is $15.38 \%$ of high school and below, $17.16 \%$ for specialist, $38.17 \%$ for undergraduate, $29.29 \%$ for master and above, $37.87 \%$ for students and $31.95 \%$ in business / company, 5.33\% in government and institutions, $18.34 \%$ for free employment, and 3500 in income distribution. The following accounted for $46.15 \%$, 3500Yuan -5000 Yuan accounted for $17.46 \%$, 5000Yuan -10000 Yuan accounted for $22.49 \%, 10000$ yuan or more accounted for $13.91 \%$.

The descriptive statistics of the sample are shown in Table 2.

Table 2. Sample population statistics

\begin{tabular}{|c|c|}
\hline \multicolumn{2}{|c|}{ sample population statistics } \\
\hline Sex & Male accounted for $43.2 \%$; women accounted for $56.8 \%$. \\
\hline Age & $\begin{array}{l}18 \text { years old and below } 2.96 \% ; 18 \text { years old }-35 \text { years old accounted for } 85.21 \% ; 35 \text { years old }-60 \\
\text { years old accounted for } 11.83 \% \text {; } 60 \text { years old and above accounted for } 0 \% \text {. }\end{array}$ \\
\hline Education & $\begin{array}{l}\text { High school and below accounted for } 15.38 \% \text {; specialist accounting for } 17.16 \% \text {; undergraduate } \\
\text { accounting for } 38.17 \% \text {; master degree and above accounted for } 29.29 \% \text {. }\end{array}$ \\
\hline Occupation & $\begin{array}{l}\text { The proportion of students is } 37.87 \% \text {, the proportion of employees in enterprises / companies is } \\
31.95 \% \text {, the proportion of government and public institutions is } 5.33 \% \text {, and that of freelancers is } \\
18.34 \% \text {. }\end{array}$ \\
\hline income & $\begin{array}{l}\text { Below } 3500 \text { yuan accounted for } 46.15 \% ; 3500 \text { yuan }-5000 \text { yuan accounted for } 17.46 \% ; 5000 \\
\text { yuan }-10000 \text { yuan accounted for } 22.49 \% ; 10000 \text { yuan or more accounted for } 13.91 \% \text {. }\end{array}$ \\
\hline
\end{tabular}

(Four) Test of reliability and validity

In the reliability test proposed by Krone Baha, if the Cronbach 's alpha coefficient is higher than 0.9 , the reliability of the questionnaire is good, and 0.7 0.8 believes that the reliability of the questionnaire is acceptable, from the reliability of the variables in Table 3 .

The data are all above the acceptable range, so the reliability of each item in the questionnaire is verified.

In the KMO measurement standard of Kaiser, if the KMO value is less than 0.5, it is not suitable for factor analysis. It is more than 0.5 from the specific data of the table $3 \mathrm{KMO}$ value. The significant probability of the Bartlett spherical test is 0 , less than 0.01 , and the factor load is more than 0.4 , so the validity of the questionnaire is higher. 
The reliability and validity test is shown in Table 3 as follows:

Table 3 . Reliability and validity test

\begin{tabular}{|c|c|c|c|c|c|}
\hline variable & $\begin{array}{l}\text { Measurement } \\
\text { dimension }\end{array}$ & Cronbach's $\alpha$ & $\begin{array}{l}\text { Degree of variable } \\
\text { interpretation }\end{array}$ & $\begin{array}{l}\text { KMO } \\
\text { value }\end{array}$ & $\begin{array}{lr}\text { Bartlett } & \text { spherical } \\
\text { test } & \text { significant } \\
\text { probability } & \end{array}$ \\
\hline \multirow{9}{*}{$\begin{array}{l}\text { Appeal of } \\
\text { perceptual } \\
\text { advertisement }\end{array}$} & Interesting content & & \multirow{9}{*}{0.78} & \multirow{9}{*}{0.92} & \multirow{9}{*}{0} \\
\hline & Lighthearted & 0.91 & & & \\
\hline & Happy & & & & \\
\hline & Social interaction & & & & \\
\hline & $\begin{array}{l}\text { Get acquainted } \\
\text { with new friends }\end{array}$ & 0.886 & & & \\
\hline & Brand interaction & & & & \\
\hline & Effect & \multirow{3}{*}{0.8} & & & \\
\hline & Intimacy & & & & \\
\hline & Popularity & & & & \\
\hline \multirow{8}{*}{$\begin{array}{l}\text { Rational } \\
\text { advertising } \\
\text { appeal }\end{array}$} & $\begin{array}{l}\text { Understanding } \\
\text { information }\end{array}$ & & \multirow{8}{*}{0.72} & \multirow{8}{*}{0.891} & \multirow{8}{*}{0} \\
\hline & Mastery of skill & 0.877 & & & \\
\hline & $\begin{array}{l}\text { Widening } \\
\text { knowledge }\end{array}$ & & & & \\
\hline & $\begin{array}{l}\text { real } \\
\text { accuracy }\end{array}$ & 0.873 & & & \\
\hline & No exaggeration & & & & \\
\hline & $\begin{array}{l}\text { Other people's } \\
\text { attention }\end{array}$ & \multirow{3}{*}{0.827} & & & \\
\hline & Coverage & & & & \\
\hline & Active response & & & & \\
\hline \multirow{3}{*}{$\begin{array}{l}\text { Brand } \\
\text { emotion }\end{array}$} & I feel fine & \multirow{3}{*}{0.9} & \multirow{3}{*}{0.76} & \multirow{3}{*}{0.848} & \multirow{3}{*}{0} \\
\hline & $\begin{array}{l}\text { In a cheerful } \\
\text { frame of mind } \\
\text { Bring fun }\end{array}$ & & & & \\
\hline & $\begin{array}{l}\text { Enjoy the } \\
\text { experience }\end{array}$ & & & & \\
\hline \multirow{3}{*}{$\begin{array}{l}\text { Brand } \\
\text { emotion }\end{array}$} & confidence & \multirow{3}{*}{0.911} & \multirow{3}{*}{0.79} & \multirow{3}{*}{0.815} & \multirow{3}{*}{0} \\
\hline & $\begin{array}{l}\text { trust } \\
\text { honest }\end{array}$ & & & & \\
\hline & reliable & & & & \\
\hline \multirow{3}{*}{$\begin{array}{l}\text { Purchase } \\
\text { intention }\end{array}$} & $\begin{array}{l}\text { Willing to } \\
\text { understand }\end{array}$ & \multirow{3}{*}{0.849} & \multirow{3}{*}{0.76} & \multirow{3}{*}{0.801} & \multirow{3}{*}{0} \\
\hline & $\begin{array}{l}\text { Willing to buy } \\
\text { Platform purchase }\end{array}$ & & & & \\
\hline & $\begin{array}{l}\text { Under line } \\
\text { purchase }\end{array}$ & & & & \\
\hline
\end{tabular}




\section{Empirical Results and Analysis}

(1) The influence of social media advertising appeals on purchase intention

Taking rational advertising appeals and perceptual advertising appeals as independent variables, and purchase intention as dependent variable, multiple regression analysis is conducted. The results are shown in Table 4.

Table 4. Regression results of social media advertising appeals to purchase intention

\begin{tabular}{llll}
\hline variable & $\beta$ & $\mathrm{t}$ & sig \\
\hline Appeal of perceptual advertised & 0.426 & 5.759 & 0 \\
Rational advertising appeal & 0.327 & 4.415 & 0 \\
F & 186.520 & & \\
R party & 0.526 & & \\
\hline
\end{tabular}

In the regression analysis, the $\mathrm{F}$ value is 186.520 and the $\mathrm{R}$ square is 0.526 , and the regression equation is obvious. The sig of the perceptual advertising appeal $(\mathrm{sig}=0)$ and the rational advertising appeal (sig=0) are less than 0.05 , so the two variables have a significant positive effect on the purchase intention, and the hypothesis 1 is verified; the influence of the perceptual advertising appeal is greater (beta $=0.426$ ). Secondly, the rational advertising appeals (beta $=0.327$ ) show that the impact of emotional advertising appeals is strongest, and rational advertising demands second.

Based on the above factor analysis and regression analysis, the weight of the factors influencing the willingness to communicate in the model is shown in Table 5.

Table 5. Weight of each factor

\begin{tabular}{|c|c|c|c|c|}
\hline variable & Measurement dimension & Factor load & $\begin{array}{l}\text { Degree of variable } \\
\text { interpretation }\end{array}$ & weight \\
\hline \multirow{9}{*}{$\begin{array}{l}\text { Appeal of } \\
\text { perceptual } \\
\text { advertisement }\end{array}$} & Interesting content & 0.874 & \multirow{9}{*}{0.78} & 0.682 \\
\hline & Lighthearted & 0.84 & & 0.655 \\
\hline & Happy & 0.822 & & 0.641 \\
\hline & Social interaction & 0.838 & & 0.654 \\
\hline & $\begin{array}{l}\text { Get acquainted with new } \\
\text { friends }\end{array}$ & 0.829 & & 0.647 \\
\hline & Brand interaction & 0.825 & & 0.644 \\
\hline & Effect & 0.694 & & 0.541 \\
\hline & Intimacy & 0.755 & & 0.589 \\
\hline & Popularity & 0.76 & & 0.593 \\
\hline \multirow{9}{*}{$\begin{array}{l}\text { Rational } \\
\text { advertising } \\
\text { appeal }\end{array}$} & $\begin{array}{l}\text { Understanding } \\
\text { information }\end{array}$ & 0.763 & \multirow{9}{*}{0.72} & 0.549 \\
\hline & Mastery of skill & 0.794 & & 0.572 \\
\hline & Widening knowledge & 0.815 & & 0.587 \\
\hline & real & 0.76 & & 0.547 \\
\hline & accuracy & 0.811 & & 0.584 \\
\hline & No exaggeration & 0.752 & & 0.541 \\
\hline & Other people's attention & 0.785 & & 0.565 \\
\hline & Coverage & 0.684 & & 0.492 \\
\hline & Active response & 0.727 & & 0.523 \\
\hline
\end{tabular}

From table 5, we can see that after factor analysis, the explanatory degrees of the variables of perceptual advertising appeal and rational advertising appeal are $78 \%$ and $72 \%$ respectively, which are higher than $70 \%$. Therefore, all the two variables divided by all factors can explain all the factors well. 
From the weight of each factor in the perceptual advertisement appeal variable, it can be seen that the content of the advertisement has great influence on the purchase intention, and the second is the social interaction and the acquaintance of the new friends. The weight of each factor in the rational advertising appeal variable can be seen, which can widen the influence of the consumer knowledge to the purchase intention, followed by the accurate content and the palmar. Hold new skills.

(Two) The test of the intermediary effect of brand attitude

The regression analysis with brand attitude as the mediator variable can be divided into three steps:

(1) Measuring the relationship between social media advertising appeal, brand attitude and purchase intention respectively, the results should be significant.

(2) Measuring the relationship between social media advertising appeal and brand attitude, the result should be significant.

(3) Take the social media advertising appeal and brand attitude into the regression equation at the same time, and measure the relationship between the two and the purchase intention. If the measured $t$ value is smaller than the value 1 , it is not significant, indicating the existence of the complete intermediary effect, which indicates that there is a partial intermediary effect.

From the data of Table 4, we can see that the positive impact of social media advertising appeals on purchase intention is significant. Taking the brand attitude as the independent variable and the purchase intention as the dependent variable, a regression analysis is carried out. The result is shown in Table 6.

Table 6. Regression results of brand attitude towards purchase intention

\begin{tabular}{llll}
\hline variable & $\beta$ & $\mathrm{t}$ & $\mathrm{sig}$ \\
\hline Appeal of perceptual advertised & 0.317 & 6.073 & 0 \\
Rational advertising appeal & 0.534 & 10.242 & 0 \\
F & 309.428 & & \\
R party & 0.648 & &
\end{tabular}

In regression analysis, the $\mathrm{F}$ value is 309.428 and the $\mathrm{R}$ side is 0.648 . Brand sentiment $(\mathrm{sig}=0$, beta $=0.317$ ) and brand trust (sig $=0$, beta $=0.534$ ) have a significant positive impact on purchase intention.

1. The test of the intermediary effect of brand emotion

Taking the perceptual advertising demand and rational advertising demand as independent variables, brand sentiment is used as a dependent variable in multiple regression analysis. The results are shown in Table 7.

Table 7. Regression results of social media advertising appeal to brand emotion

\begin{tabular}{llll}
\hline variable & $\beta$ & $\mathrm{t}$ & $\mathrm{sig}$ \\
\hline Appeal of perceptual advertised & 0.512 & 8.175 & 0 \\
Rational advertising appeal & 0.331 & 5.391 & 0 \\
F & 327.398 & & \\
R party & 0.661 & &
\end{tabular}

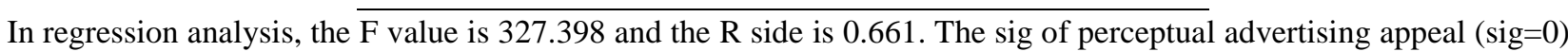
and rational advertising appeal (sig=0) are all less than 0.05 , so the two variables have significant influence on brand emotion. Among them, the appeal of perceptual advertising has a greater impact (beta $=0.512$ ), followed by rational advertising appeals (beta $=0.331$ ). It shows that advertising appeal can significantly affect user brand emotion.

The multiple regression analysis is based on the emotional advertising demand, rational advertising appeal and brand sentiment as the dependent variable, and the purchase intention as the dependent variable. The results are shown in Table 8 . 
Table 8. Regression results of brand emotional mediator effect

\begin{tabular}{lllll}
\hline variable & $\beta$ & $\mathrm{t}$ & $\mathrm{sig}$ & Test results \\
\hline Appeal of perceptual advertised & 0.209 & 2.757 & 0.006 & $\mathrm{t}<8.175, \mathrm{sig}<0.05$, Significant, part of the intermed \\
Rational advertising appeal & 0.186 & 2.585 & 0.01 & $\mathrm{t}<5.391, \mathrm{sig}<0.05$, Significant, part of the intermed \\
Mediator variable & & & & \\
Brand emotion & 0.425 & 7.009 & 0 \\
F & 158.692 & & \\
R party & 0.585 &
\end{tabular}

In regression analysis, the $\mathrm{F}$ value is 158.692 and the $\mathrm{R}$ side is 0.585 . After adding brand emotion as the independent variable, the perceptual advertising appeal $(\mathrm{sig}=0.006)$ still has a significant influence on the purchase intention, and the rational advertising appeal (sig=0.01) still has a significant influence on the purchase intention. According to the analysis of the above regression results, the brand emotion plays a part of the intermediary effect in the relationship between the advertising appeal and the purchase intention, assuming that 2 is obtained. To verify.

2. The test of the intermediary effect of brand trust

Taking the perceptual advertising demand and rational advertising demand as independent variables, brand sentiment is used as a dependent variable in multiple regression analysis. The results are shown in Table 9.

Table 9. Regression results of social media advertising appeals to brand trust

\begin{tabular}{llll}
\hline variable & $\beta$ & $\mathrm{t}$ & $\mathrm{sig}$ \\
\hline \multicolumn{2}{l}{ Appeal of perceptual advertised 0.445} & 6.005 & 0 \\
Rational advertising appeal & 0.307 & 4.136 & 0 \\
$\mathrm{~F}$ & 185.529 & & \\
R party & 0.524 & &
\end{tabular}

In regression analysis, the $\mathrm{F}$ value is 185.529 and the $\mathrm{R}$ side is 0.524 . The sig of perceptual advertising appeal $(\mathrm{sig}=0)$ and rational advertising claim $(\mathrm{sig}=0)$ are all less than 0.05 , so the two variables have significant influence on brand trust. Among them, the appeal of perceptual advertising has a greater impact (beta $=0.445$ ), followed by rational advertising appeals (beta $=0.307$ ). It shows that advertising appeals can significantly affect user brand trust.

The multiple regression analysis is based on the emotional advertising demand, the rational advertising appeal and brand trust as the independent variable, and the purchase intention as the dependent variable. The results are shown in table 10 .

Table 10. Regression results of brand trust mediator effect

\begin{tabular}{lllll}
\hline variable & $\beta$ & $\mathrm{t}$ & $\mathrm{sig}$ & $\mathrm{T}$ Test results \\
\hline Appeal of perceptual advertised & 0.187 & 2.843 & 0.005 & $\mathrm{t}<6.005$,sig $<0.05$, Significant, part of the intermed \\
Rational advertising appeal & 0.162 & 2.529 & 0.012 & $\mathrm{t}<4.136$,sig $<0.05$, Significant, part of the intermed \\
Mediator variable & & & & \\
Brand trust & 0.538 & 11.642 & 0 & \\
F & 219.755 & & & \\
R party & 0.662 & & & \\
\hline
\end{tabular}

In regression analysis, the $\mathrm{F}$ value is 219.755 and the $\mathrm{R}$ side is 0.662 . After joining the brand trust as the independent variable, the perceptual advertising appeal $(\mathrm{sig}=0.005)$ still has a significant impact on the purchase intention, and the rational advertising appeal $(\mathrm{sig}=0.012)$ still has a significant impact on the purchase intention. According to the analysis of the above regression results, it can be found that brand trust plays a part of the intermediary effect hypothesis in the relationship between the advertising appeal and the purchase intention 3. Verification. 


\section{Research Summary and Countermeasures and Suggestions}

This study, based on the theory of attitude change and rational behavior, explores the mediating effect of brand attitude on the influence of the social media advertising appeal on the purchase intention of clothing consumers on the basis of the literature review of advertising appeal and purchase intention, combining the social media environment and the characteristics of the clothing industry. The theoretical model of "advertising appeal in the social media environment - the willingness to buy clothing consumers" was proposed, and 8 hypothesis paths were constructed, and 35 measurement items were established for the five dimensions of perceptual advertising appeal, rational advertising appeal, brand emotion, brand trust and purchase intention. Then the descriptive statistics, reliability, validity test and factor analysis are carried out through pre investigation and large-scale investigation, data recovery and sorting and entry, reliability, validity test and factor analysis to ensure that the questionnaire data have reached the statistical requirements and the rationality of the selection of the index. The data processing software SPSS is used to test the model of this paper. The rationality of the model is verified, the hypotheses proposed in this paper are tested, and the relevant research contents of advertising influence are perfected.

By classifying advertising appeals into perceptual advertising appeals and rational advertising appeals, brand attitude is classified as brand emotion and brand trust, the theoretical model of brand emotion and brand trust in the relationship of advertising appeal and purchase intention is constructed under the social media environment, and the model is carried out through empirical research. The following conclusions are concluded:

(1) advertising appeals have a significant positive impact on clothing consumers' purchase intention in the social media environment. The appeal of perceptual advertising has greater influence on the purchase intention of clothing consumers than rational advertising appeal. According to factor molecules, it is found that the content of content, social interaction and the influence of new friends on purchasing intention are greater. New skills have a great impact on the willingness to buy.

(2) brand sentiment and brand trust play a mediating role in the impact of advertising appeals on clothing consumers' purchase intention in the social media environment. The influence of brand trust on the purchase intention of clothing consumers is stronger than brand emotion, and perceptual advertising appeal has a stronger influence on brand emotion and brand trust than rational advertising appeal.

Based on the questionnaire survey data, this paper uses regression analysis to test the intermediary effect, and empirically analyses the influence of the media advertising appeal of the social media with the user's purchase intention through the intermediary effect of the brand attitude. The research finds that the advertising appeal has a significant positive impact on the consumer's purchase intention, and the brand attitude plays a part of the mediating effect on the positive impact of the advertising appeal and the purchase intention. Therefore, the enterprises should use social media to improve the willingness of the media to buy, which should be started from the following aspects:

\section{The appeal of perceptual advertising}

Through this study, it can be concluded that enterprises can add more positive and positive language in social media advertising, which makes consumers connect the impression with advertising products, enhances the entertainment of the content, make the content easy and happy, and make it happy, and join the more exaggerated language. The mood swings, the interaction of the content, the interaction with others, and the recognition of more friends, the influence of the people, the increase of the influence of the communicators, and the choice of people with high visibility and high influence to disseminate the content.

\section{The appeal of rational advertising}

Through this study, it can be concluded that enterprises can increase more professional information in social media advertising, let consumers understand more practical skills through advertising, broaden the knowledge side, display the high functionality of the product through advertising, and use a large number of data language to make consumers feel that the content is true and reliable, through multiple parties. The experiment confirms the accuracy of product advertising and there is no exaggeration; a large number of other consumers have also bought this product through large data, and are actively responding to a wide range of coverage and will also promote the willingness of consumers to buy.

\section{Brand emotion}

This research can also enhance the purchase intention by enhancing the brand sentiment of the consumer, adding the content that can arouse the consumer's influence on the brand (merchant) in the advertising propaganda, and link the brand with the public welfare, green environment and life attitude to make the consumer feel very good to the brand 
and is happy. It is fun to make consumers feel that buying goods from this brand is a very enjoyable experience by strengthening customer service attitude and offering small gifts.

\section{Brand trust}

This study can also enhance the consumer's brand trust to enhance the willingness to buy. It can be added to the advertisement to increase the trust of the brand, or to say do it or the consumer's comments, to strengthen the brand trust of the consumer, to put on the professional clothes for the people of the advertisement, and to add the experiment in the advertisement. In part, the impression of businessmen in the eyes of consumers is trustworthy, honest and reliable.

\section{Research Prospect}

At present, social media such as WeChat and micro-blog have become a comprehensive platform for people to obtain advice, feel pleasure, express their views and maintain relations. The competition of such social media is becoming increasingly fierce. This will lead to more changes in the future and more complex characteristics. Social media advertising marketing will also become a change. The focus of this study should be given enough attention. This study analyzes the relationship between the advertising appeal and the purchase intention of clothing consumers, and constructs a structural model, but there are still many shortcomings. The follow-up will continue to expand and complement the research. The future will begin from the following aspects:

(1) expand the scope of the sample, rather than too many college students as respondents, ignoring the differences between users. In this way, we can know the real situation and influencing factors of the purchase intention of advertising appeals under the social media environment by users of various age levels, educational background, work field and income class.

(2) to increase more influential factors and to design a more perfect index system, then collect data through a large-scale questionnaire survey, and finally extract the most important factors through data analysis, thus avoiding the problems caused by the subjective judgment of the researchers and making the research more scientific.

(3) not limited to consumers in the clothing industry, follow-up researchers can build models in other industries and expand on this basis to expect more innovative results.

\section{References}

Chen Dong. (2014). The relationship between consumer brand perceived value and brand identity in different advertising appeals. Southwestern University of Finance and Economics.

Chen Kai. (2016). Research on the influence of advertising appeal and impression management motivation on green purchase intention. Resource development and market, 32(10), 1204-1208. https://doi.org/1 0.3969/j.issn.1005-8141.2016.10.010.

Fishbein M, Ajzen I. (1975). Belief, Attitude, Intention, and Behavior: An, Behavior.

Gary M. Mullet \& Marvin Karson. Analysis of Purchase Intent Scales.

Li Qiong, Wu Zuomin. (2008). A summary of the research on the mechanism of advertising attitude and brand attitude. advertising in China, (11), 137-140.

Liu Jianxin. (2017). The parallel multiple intermediary mechanism. Nankai management review, which affects the consumer's purchase intention by the demand for product scarcity, 20(4), 4-15. doi:10.3969/j.issn.1008-3448.2017.04.002.

Nena Lim. (2003). Consumers "perceived risk: sources versus consequences. Electronic Commerce Commerce Electronic, 10(3). https://doi.org/10.1016/S1567-4223(03)00025-5

Wang Huaiming, Chen Yiwen. (1999). Advertising appeal form and consumer psychological processing mechanism. psychological science, 22(5), 475 - 476

Wang Huaiming. (1999). The influence of rational advertising and emotional advertising on consumer brand attitude. psychology dynamics, 7(1), 56-59. https://doi.org/10.3969/j.issn.1671-3710.1999.01.012.

Wang Xia. (2012). The influence of advertising appeal and brand personality perception difference on Consumer $\begin{array}{llll}\text { Purchase Intention Research. } & \text { Management Journal, } & \text { 5(4), }\end{array}$ https://doi.org/10.3969/j.issn.1672-884X.2012.04.012.

Xie Yi, Peng Siqing. (2014). The influence of brand trust and brand sentiment on word of mouth: the role of attitude and attitude uncertainty. management review, 26(02), 80-91. 
Yu Ting Ting. (2013). Marketing communication strategy innovation based on social media reputation. journalism University, (3), 115-120. https://doi.org/10.3969/j.issn.1006-1460.2013.03.018.

Yuan Denghua, Luo Siming, Fu Chun Jiang, Xie Ying Qin. (2010). Influence of advertising intervention on consumer brand attitude and trust. Journal of psychology, 42(06), 715-726. 